\title{
CHRONIC PHYSICAL STRESS CHANGES GENE EXPRESSION OF CATECHOLAMINE BIOSYNTHETIC ENZYMES IN THE ADRENAL MEDULLA OF ADULT RATS
}

GAVRILOVIĆ LJUBICA, STOJILJKOVIĆ VESNA, KASAPOVIĆ JELENA, PEJIĆ SNEŽANA, TODOROVIĆ ANA, PAJOVIĆ B SNEŽANA and DRONJAK SLADJANA

University of Belgrade, Institute of Nuclear Sciences "Vinča", Laboratory of Molecular Biology and Endocrinology, Serbia

(Received 17 ${ }^{\text {th }}$ November 2011)

In this study we examined how chronic forced running (CFR) affects the expression of catecholamine biosynthetic enzymes and CAMP response element-binding (CREB) in the adrenal medulla and the weight of adrenal glands of rats. Also, we examined how CFR and additional acute immobilization stress affect the expression of catecholamine biosynthetic enzymes in the adrenal medulla and the concentration of catecholamines and corticosterone (CORT) in the blood plasma.

In this experiment we used as a model forced exercise in rats (treadmill running). We used the most advanced method for determining the level of gene expression, Real-time PCR with TaqMan probes, as well as Western blot analysis (ECL).

We found that CFR decreases tyrosine hydroxylase (TH), and dopamine- $\beta$-hydroxylase (DBH) mRNA and protein levels in the adrenal medulla. The decreased TH and DBH mRNA levels coincide with the reduced expression of CREB in the adrenal medulla and with the reduced plasma CORT level. Additionally, CFR reduces the level of phenylethanolamine N-methyltransferase (PNMT) mRNA, but elevates its protein level in the adrenal medulla and increases the concentration of adrenaline $(A)$ in the plasma. Reduced level of PNMT mRNA in the adrenal medulla coincides with reduced plasma CORT level. The additional acute immobilization stress increases gene expression of catecholamine biosynthetic enzymes in the adrenal medulla, as well as catecholamines and CORT levels in the plasma.

The increased synthesis of PNMT enzyme in the adrenal medulla may result in an increased biosynthesis of $A$ under chronic stress conditions. Additionally, increased level of catecholamines in the plasma after chronic physical stress is the allostatic load that may induce numerous diseases and pathological conditions.

Key words: acute immobilization stress, adrenal medulla, catecholamine, chronic stress, gene expression 


\section{INTRODUCTION}

Forced modes of exercise, like treadmill training, may cause physiological adaptations indicative for chronic stress (Moraska et al., 2000). Literature data indicates that treadmill runing is a combination of hard physical and psychological stressors. An alternative to forced exercise paradigms is to allow experimental animals free access to running wheels and allow exercising voluntarily for extended periods of time. Using this method, the stressor effects of forced training schedules can be avoided (Erdös et al., 2007). In this study we applied a model of chronic forced exercise (CFR), which by the intensity and duration, could simulate intense physical activity. We exposed the animals to a long-term 12-weeks forced running because few reports suggested that forced running induce adaptations that are indicative for chronic stress. Morasca et al. (2000) showed that treadmill training for a period of 8 weeks (10-60 min daily, $17.4-29.2 \mathrm{~m} / \mathrm{min}$ ), may cause physiological adaptations indicative for chronic stress. The purpose of this study was to characterize the effect of long-term treadmill running on potentially negative adaptations. It is known that chronic stress can contribute significantly to the development of various serious diseases such as hypertension, cancers, depression and psychiatric diseases.

In this work we investigated how CFR and additional acute immobilization stress (CFR+IMM) affect the mRNA and protein levels of catecholamine biosynthetic enzymes in the adrenal medulla, as well as how CFR affects the expression of cAMP response element-binding protein (CREB), and the weight of adrenal glands. One of the key questions in stress research is how the same stressor can elicit a variant or altered response depending on prior experience with the current or different stressor. By using chronic and acute stressors, we explored whether the chronically stressed rats exposed to novel, additional, acute stress exhibited exaggerated responses of gene expression of catecholamine biosynthetic enzymes in the adrenal medulla.

Tyrosine hydroxylase (TH), as the "rate-limiting" enzyme in the biosynthesis of catecholamines, is localized in all cells that produce catecholamines. TH catalyzes the hydroxylation of tyrosine into dopamine (DA) (Nagatsu et al., 1964). Dopamine- $\beta$-hydroxylase (DBH) is another important catecholamine biosynthetic enzyme which converts DA into NA. Phenyl ethanolamine N-methyltransferase (PNMT) is considered as the second "rate-limiting" enzyme for the synthesis of adrenaline $(A)$, especially under the influence of strong stressors (Kvetnansky et al., 2004).

The promoter region of TH gene contains three sites (CRE, AP1 and SP1/Egr1) for the binding of transcription factors in response to stress. Many authors documented that glucocorticoids affect the transcription and activity of TH (Tank et al., 1986; Lewis et al., 1987). Nunez at al. (2009) showed that the increase of corticosterone (CORT) induce the increase of expression and enzyme activity of TH. TH activity is particularly important for catecholamine synthesis and is time-dependent and controlled by different mechanisms (Kumer and Vrana, 1996). 
Acta Veterinaria (Beograd), Vol. 62, No. 2-3, 151-169, 2012.

Dopamine- $\beta$-hydroxylase (DBH) is another important catecholamine biosynthetic enzyme which converts dopamine (DA) into noradrenaline (NA). $\mathrm{DBH}$ gene transcription requires the binding of AP1 family members, including CFos and C-Jun, as well as the CRE/AP1 site (Swanson et al., 2000). DBH gene expression is also regulated by glucocorticoids, and several putative sites have been identified in the rat DBH promoter (Hwang and Joh, 1993; McMahon and Sabban, 1992).

Phenyl ethanolamine N-methyltransferase (PNMT) is considered as the second "rate-limiting" enzyme for the synthesis of adrenaline (A), especially under the influence of strong stressors (Kvetnansky et al., 2004). Glucocorticoids are important regulators of PNMT gene expression on transcriptional and posttranslation level (Wong et al., 1992). A glucocorticoid responsive element (GRE) was initially identified at $-533 \mathrm{bp}$ of the rat PNMT promoter (Ross et al., 1990). Subsequently, two further upstream overlapping GREs at -759 bp and -773 bp of the rat promoter were found to be the primary sites involved in the regulation of the PNMT gene by glucocorticoids (Tai et al., 2002).

In addition we examined the impact of the CFR and CFR+IMM on the concentrations of NA, A and morning corticosterone (CORT) in the plasma of rats.

Detecting regulatory physiological mechanisms for catecholamine synthesis in the adrenal medulla in stress conditions provoked by forced prolonged intensive running is extremely important in the prevention of numerous diseases and pathological conditions.

\section{MATERIAL AND METHODS}

\section{Animals and treadmill running}

In this study Wistar male rats (11-week-old) were used. Animals were under standard laboratory conditions with water and food ad libitum and kept three to four per cage. The care was taken to minimize the pain and discomfort of the animals according to the recommendations of the Ethical Committee of the "Vinča" Institute of Nuclear Sciences, Belgrade, Serbia, which are in accordance with the Guide for Care and Use of Laboratory Animals of the National Institute of Health, Bethesda, MD, U.S.A.

Animals were divided into four groups with ten animals in each: i) The control group was not exposed to any treatment; ii) CFR group consisted of animals exposed to chronic forced running for a period of 12 weeks; iii) IMM group consisted of animals exposed to acute stress immobilization, for a period of $2 \mathrm{~h}$, and iv) CFR+IMM group consisted of animals exposed to CFR stress for a period of 12 weeks, and after chronic stress, these animals are exposed to additional acute IMM stress for a period of $2 \mathrm{~h}$.

Chronic forced running was achieved by rats running daily on a treadmill. The duration and speed of running was gradually increased from week to week, from the initial $10 \mathrm{~min}-10 \mathrm{~m} / \mathrm{min}$ up to $20 \mathrm{~min}-20 \mathrm{~m} / \mathrm{min}$ at $0^{\circ}$ inclination. The treadmill training protocol used in this study involves a gradual increase in running intensity and is commonly used in the similar studies. 
Immobilization stress was provoked as described by Kvetnansky and Mikulaj (1970). The animals were sacrificed after chronic stress, immediately after the cessation of acute immobilization and $3 \mathrm{~h}, 6 \mathrm{~h}$ and $22 \mathrm{~h}$ after acute immobilization. In these periods changes in gene expression of catecholamine biosynthetic enzymes in the adrenal medulla are expected. Samples of blood were collected and both adrenal medulla were isolated. Adrenal medulla were immediately frozen and stored in liquid nitrogen until analyzed.

To determine whether CFR affects the diurnal rhythm of CORT in this experiment, we used morning CORT.

RNA isolation and $c D N A$ synthesis

Total RNAs were isolated using TRIZOL reagent (Invitrogen, USA). After the isolation of mRNA, DNA-ase treatment was applied with DNAse I (Fermentas, Lithuania). Concentration of total mRNA was measured in triplicates on a spectrophotometer. Quality of mRNA was checked on agarose gel. Reverse transcription was performed using Ready-To-Go You-Prime First-Strand Bead (Amersham Biosciences, UK) and pd $(\mathrm{N})_{6}$ Random Hexamer (Amersham Biosciences, UK) primer according to the manufacturer's protocol.

\section{Real-time RT-PCR}

TaqMan PCR assays were carried out using Assay-on-Demand Gene Expression Products (Applied Biosystems,USA) for TH (Rn00562500_m1), DBH (Rn00565819_m1), PNMT (Rn01495589_g1) and CREB (Rn01441386__g1). The gene expression assays contained primers for the amplification of the target gene and the TaqMan MGB (Minor Groove Binder) probe 6-FAM dye-labeled for quantification. Reactions were performed in a $25 \mu \mathrm{L}$ reaction mixture containing 1x TaqMan Universal Master Mix with AmpErase UNG, 1x Assay Mix (Applied Biosystems, USA) and cDNA template (10 ng of RNA converted to cDNA). PCR was carried out in the $\mathrm{ABI}$ Prism 7000 Sequence Detection System at $50^{\circ} \mathrm{C}$ for 2 min, $95^{\circ} \mathrm{C}$ for $10 \mathrm{~min}$, followed by 40 cycles at $95^{\circ} \mathrm{C}$ for $15 \mathrm{~s}$ and $60^{\circ} \mathrm{C}$ for $1 \mathrm{~min}$. The experimental threshold was calculated based on the mean baseline fluorescence signal from cycle 3 to 15 plus 10 standard deviations. The point at which the amplification plot crosses this threshold defined as $\mathrm{Ct}$, represents the cycle number at this point and it is inversely proportional to the number of target copies present in the initial sample. Each sample was run in triplicates and the mean value of each $\mathrm{Ct}$ triplicate was used for further calculations. The reference gene (endogenous control) was included in each analysis to correct for the differences in the inter-assay amplification efficiency and all transcripts were normalised to cyclophyline A (Rn00690933 m1;) expression. The reaction mixture for endogenous control gene amplification consisted of 1x TaqMan Universal Master Mix with AmpErase UNG (Applied Biosystems, USA), 1x Assay (6-FAM dye-labeled MGB probes) and CDNA (10 ng of RNA converted to CDNA). The levels of expression of cyclophyline $A$ in samples under different treatments were checked by additional experiments that confirmed that the chosen reference gene was not regulated. Before quantification, validation experiments were performed to determine the similar amplification efficiency of endogenous control 
and each target gene. Cyclophyline A was tested and demonstrated that its efficiency of amplification was approximately equal to all assays used for target genes. Briefly, serial dilutions of CDNA were prepared and amplified by real-time PCR using specific primers and fluorogenic probes for target and endogenous control gene.

Quantification was done using the $2^{-\Delta \Delta C t}$ method according to Livak and Schmittgen (2001). The obtained results were analyzed by the RQ Study Add On software for 7000 v 1.1 SDS instrument (ABI Prism Sequence Detection System, Applied Biosystems, USA) with a confidence level of $95 \%(p<0.05)$. The relative expression of the target gene was normalized to cyclophyline $A$ and expressed in relation to the calibrator, i.e. the control sample. Due to individual differences among animals, one sample from control group with the expression value closest to the mean of all samples in this group and with the lowest measurement error was chosen as a calibrator. The results are reported as a fold change relative to the calibrator and normalized to cyclophyline A using the equation: $\mathrm{N}_{\text {sample }}=2^{-\Delta \Delta \mathrm{Ct}}$.

\section{Western blot analysis}

Adrenal medulla were homogenized in $0.05 \mathrm{M}$ sodium phosphate buffer $(\mathrm{pH}$ 6.65). Subsequently, the protein concentration was determined using BCA metod (Pierce, USA), described by Stich (1990). The samples were boiled in denaturing buffer according to Laemmli (1970), for $5 \mathrm{~min}$ at $95^{\circ} \mathrm{C}$. Fifteen microgram of protein extract from adrenal medulla was separated by $10 \%$ SDS-polyacrylamide gel electrophoresis and then transferred to a supported nitrocellulose membrane (Hybond ${ }^{\mathrm{TM}} \mathrm{C}$ Extra, Amersham Biosciences, UK). The membrane was blocked in $5 \%$ non-fat dry milk in Tris-buffered saline-Tween (TBST). All following washes and antibody incubations were also carried out in TBS-T at room temperature on a shaker. Protein molecular mass standards (PageRuler ${ }^{\mathrm{TM}}$ Plus Prestained Protein Ladder, Fermentas) were used for calibration. Antibodies used for quantification of specific proteins were as folows: for TH the monoclonal primary antibody against mouse TH (monoclonal antibody against TH from mouse-mouse hybrid cells, clone 2/40/15, dilution 1:5000, Chemicon International, USA), for DBH the anti-dopamine- $\beta$ hydroxylase ( $\mathrm{N}$-terminal) antibody, sheep (dilution 1:5000, Sigma, USA), for PNMT the polyclonal ant-PNMT primary antibody, rabbit (dilutation 1:1000, Protos Biotech Corporation, USA) and for $\beta$-actin the rabbit polyclonal anti- $\beta$-actin (ab8227, dilutation 1:5000, Abcam, USA). After washing, the membranes were incubated in the secondary anti-mouse, anti-rabbit (dilution 1:5000, Amersham ECL ${ }^{\mathrm{TM}}$ Western Blotting Analysis System, UK) and anti-sheep (dilution 1:5000, Calbiochem, Germany) antibodies conjugated to horseradish peroxidase. A secondary antibody was then visualized by the Western blotting enhanced chemiluminiscent detection system (ECL, Amersham Biosciences, UK). Membranes were exposed to ECL film (Amersham Biosciences, UK). Densitometry of protein bands on ECL film was performed by Image $\mathrm{J}$ analysis PC software. The result was expressed in arbitrary units normalized in relation to $\beta$ actin. 


\section{Catecholamine and CORT measurements}

Plasma catecholamines were measured by a standard radioenzymatic assay described previously by Peuler and Johnson (1977) and the values were expressed as $\mathrm{pg} / \mathrm{mL}$ plasma. Catecholamines present in plasma aliquots were converted to their labeled O-methylated derivatives by $\mathrm{S}-(3 \mathrm{H})$ adenosylmethionine (Lacomed, Czech Republic) and the lyophilized catechol-Omethyl transferase isolated from the rat liver. The O-methylated derivatives of the amines were then extracted along with unlabeled carrier compounds.

Plasma CORT was measured upon prior extraction directly, using RIA commercial kits (MP Biomedicals, Germany) and the values were expressed as ng CORT/mL plasma.

\section{Data analysis}

The data are presented as means \pm S.E.M. Differences of gene expression (mRNA and protein levels) of catecholamine biosynthetic enzymes $\mathrm{TH}, \mathrm{DBH}$, PNMT and level of CREB mRNA in the adrenal medulla and concentration of NA, A and CORT in the plasma, as well as weights of adrenal glands were analyzed by One-way ANOVA. Effects of chronic forced running (CFR) and acute immobilization stress (IMM) compared to control, as well as the effects of additional acute immobilization stress after hronic forced running (CFR+IMM) compared to hronic forced running animals (CFR), were tested by Tukey post-hoc test.

Statatistical significance $(p)$ was set to 0.001 , statistical power (1- $\beta$ ) exceeded $85 \%$. Statistical power confirms that the number of animals $(n=10)$ was sufficient for this experiment. Reliability test was designed so we did three repeated measurements of the level of gene expression of TH, DBH, PNMT and CREB. The calculated value of the ICCR test of $>0.85$ was considered to be satisfactory and it proves the reliability of the applied methods. Statistical analysis was carried out using SPSS.

\section{RESULTS}

One-way ANOVA analysis revealed significant changes of $\mathrm{TH}(\mathrm{F}=11.8$; $p<0.001)$, DBH $(\mathrm{F}=13.3 ; p<0.01)$, PNMT $(\mathrm{F}=8.97 ; p<0.05)$ mRNA levels, and $\mathrm{TH}$ $(\mathrm{F}=11.2 ; p<0.01)$, $\mathrm{DBH}(\mathrm{F}=10.3 ; p<0.05)$, $\mathrm{PNMT}(\mathrm{F}=3.9 ; p<0.01)$ protein levels in the adrenal medulla, as well as NA $(\mathrm{F}=29.8 ; p<0.01), \mathrm{A}(\mathrm{F}=18.7 ; p<0.01)$, CORT $(F=21.70 ; p<0.001)$ plasma concentrations and weight of adrenal glands $(\mathrm{F}=12.37 ; p<0.05)$ under examined stress conditions. glands

Changes in plasma concentrations of CORT, NA, A and weight of adrenal

CFR treatment

After CFR treatment, the decrease in plasma concentration of CORT by $15 \%$ $(p<0.05$, Tukey test, Figure 1a), increase of NA by $20 \%(p<0.05$, Tukey test, Figure $1 b)$, increase of $A$ by $25 \%(p<0.05$, Tukey test, Figure $1 c)$ and increase 
Acta Veterinaria (Beograd), Vol. 62, No. 2-3, 151-169, 2012.

weight of adrenal glands by $36 \%(p<0.05$, Tukey test, Figure $1 d)$ were detected, compared with control animals.

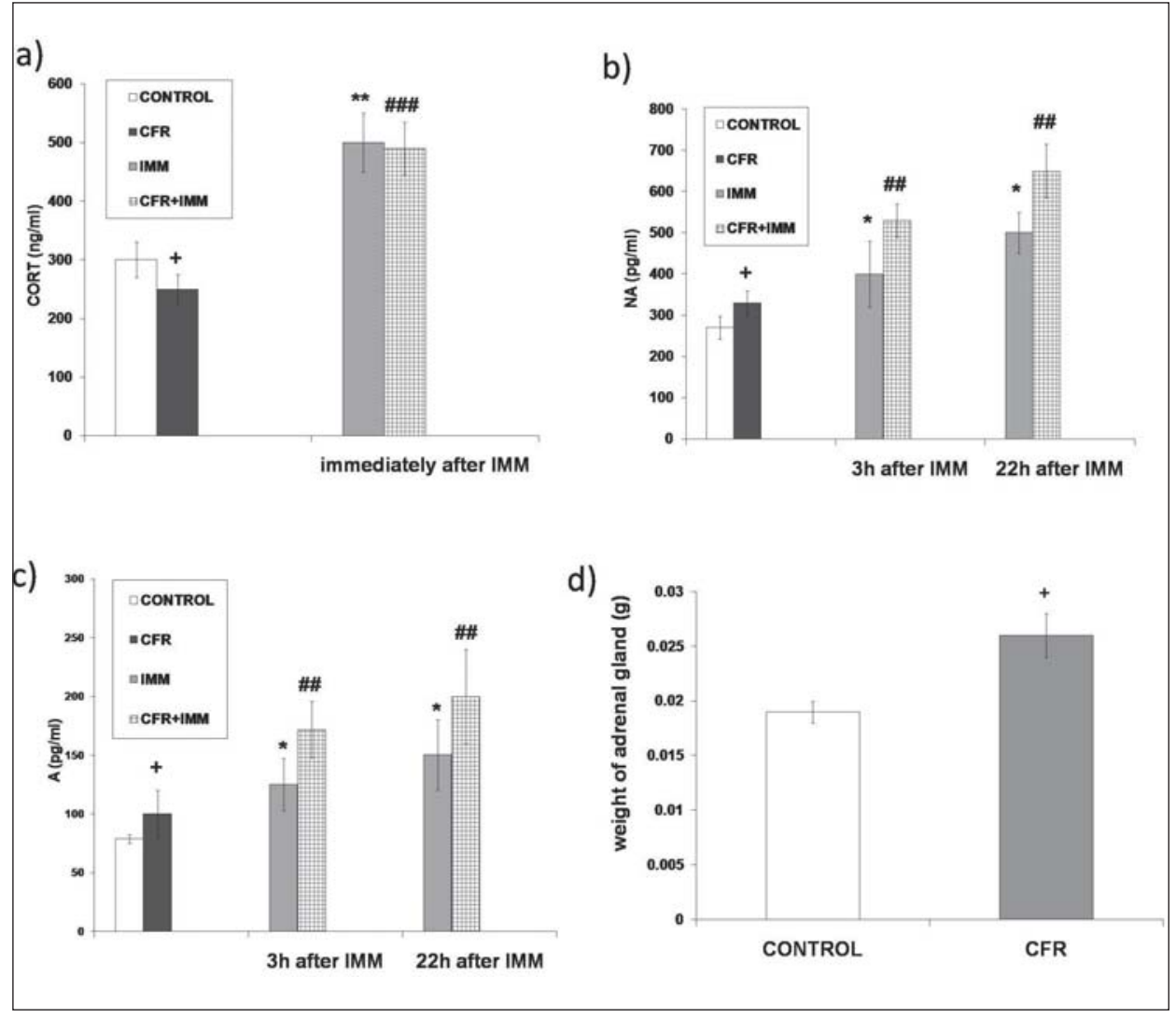

Figure 1. Effects of chronic forced running and additional acute immobilization stress on the concentration of corticosterone (CORT) [a], noradrenaline (NA) [b] and adrenaline (A) [C] in the plasma, as well as effect of chronic forced running on the weight of adrenal glands [d]. The values are means \pm S.E.M. of 10 rats. Statistical significance: $+p<0.05$ animals exposed to chronic forced running vs. control animals (Tukey test); ${ }^{*} p<0.05,{ }^{* *} p<0.01$ animals exposed to acute $2 \mathrm{~h}$ immobilization vs. control animals (Tukey test); ${ }^{\# \#} p<0.01$, \#\#\# $p<0.001$ animals exposed to additional acute $2 \mathrm{~h}$-immobilization stress after chronic forced running $v s$. animals exposed to chronic forced running (Tukey test).

\section{IMM and CFR+IMM treatment}

Exposure of animals to acute immobilization stress, led to increased CORT concentration by $66 \%(p<0.01$, Tukey test, Figure $1 \mathrm{a})$ in the plasma, immediately after the cessation of immobilization. However, the exposure of CFR animals to additional acute immobilization stress led to increased CORT concentration by 
$96 \%(p<0.001$, Tukey test, Figure 1a) in the plasma, immediately after the cessation of immobilization.

Exposure of the animals to acute immobilization stress, led to increased NA concentration by $48 \% \quad(p<0.05$, Tukey test $) 3 \mathrm{~h}$ after the cessation of immobilization, and by $85 \%(p<0.05$, Tukey test) $22 \mathrm{~h}$ after the cessation of immobilization, compared to the control group (Figure 1b). The additional acute immobilization of CFR animals increased the NA concentration by $60 \%(p<0.01$,

a)

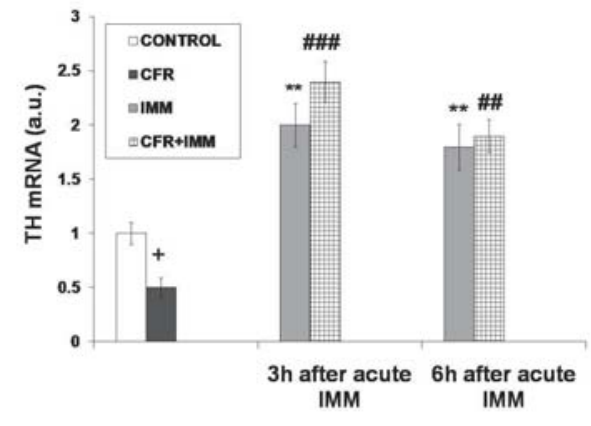

c)

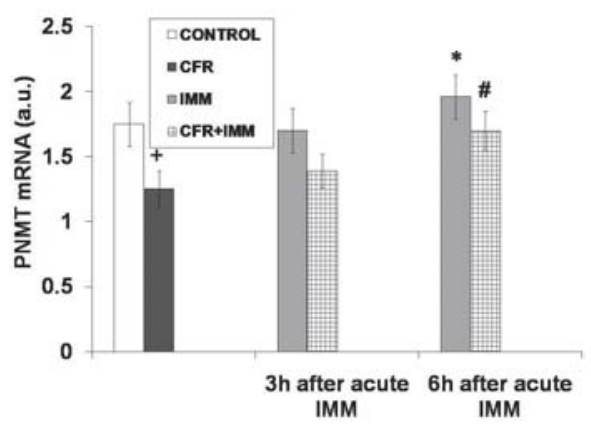

b)

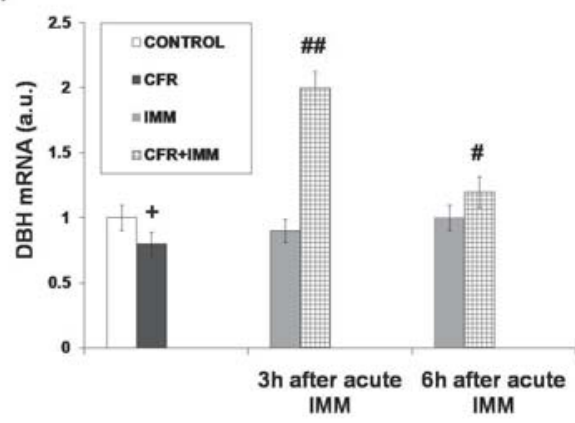

d)

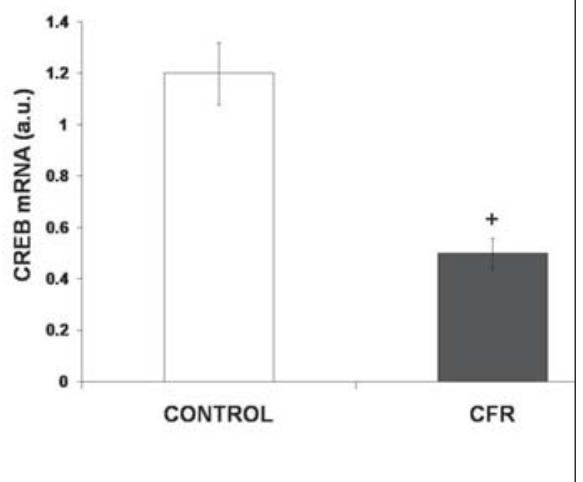

Figure 2. Effects of chronic forced running and additional acute immobilization stress on tyrosine hydroxylase (TH) [a], dopamine-B-hydroxylase (DBH) [b], phenylethanolamine N-methyltransferase (PNMT) [c] and cAMP response elementbinding (CREB) [d] mRNA levels in the adrenal medulla. The values are means \pm S.E.M. of 10 rats. Statistical significance: $+p<0.05$ animals exposed to chronic forced running vs. control animals (Tukey test); ${ }^{*} p<0.05,{ }^{*} p<0.01$ animals exposed to acute $2 \mathrm{~h}$ immobilization vs. control animals (Tukey test); ${ }^{\#} \mathrm{p}<0.05$, $\# \# p<0.01$, $\# \# \#<0.001$ animals exposed to additional acute $2 \mathrm{~h}$ immobilization stress after chronic forced running vs. animals exposed to chronic forced running (Tukey test). The final result was expressed as fold change relative to the calibrator and normalized to cyclophyline A 
Acta Veterinaria (Beograd), Vol. 62, No. 2-3, 151-169, 2012.

Gavrilović Ljubica et al.: Chronic physical stress changes gene expression

of catecholamine biosynthetic enzymes in the adrenal medulla of adult rats

Tukey test) 3h after the cessation of immobilization, and by $96 \%(p<0.01$, Tukey test) $22 \mathrm{~h}$ after the cessation of immobilization (Figure $1 \mathrm{~b}$ ).

Exposure of the animals to acute immobilization stress, led to increased $\mathrm{A}$ concentration by $60 \% \quad(p<0.05$, Tukey test $) 3 \mathrm{~h}$ after the cessation of immobilization, and by $92 \% \quad(p<0.05$, Tukey test) $22 \mathrm{~h}$ after the cessation of immobilization, compared to the control animals (Figure 1c). The additional acute immobilization of CFR rats increased the A concentration by $71 \%(p<0.01$, Tukey test) $3 \mathrm{~h}$ after the cessation of immobilization, and by $100 \%(p<0.01$, Tukey test) $22 \mathrm{~h}$ after the cessation of immobilization (Figure 1c).

Changes of TH, DBH, PNMT and CREB mRNA levels in the adrenal medulla

CFR treatment

CFR affected the mRNA levels of TH, DBH, PNMT and CREB in the adrenal medulla (Figure 2a, 2b, 2c and 2d). The animals exposed to CFR showed a decreased level of TH mRNA by $50 \%$ ( $p<0.05$, Tukey test), DBH mRNA by $18 \%$ $(p<0.05$, Tukey test), PNMT mRNA level by $39 \%(p<0.05$, Tukey test) and CREB mRNA by $56 \%(p<0.05$, Tukey test) compared with control animals.

\section{IMM and CFR+IMM treatment}

Exposure of the animals to acute stress immobilization, increased the level of TH mRNA by $100 \% \quad(p<0.01$, Tukey test $) 3 \mathrm{~h}$ after the cessation of immobilization, and by $90 \%(p<0.01$, Tukey test) $6 \mathrm{~h}$ after the cessation of immobilization (Figure 2a). In addition, acute stress immobilization, increased the level of PNMT mRNA by $14 \%(p<0.05$, Tukey test, Figure $2 \mathrm{c}) 6 \mathrm{~h}$ after the cessation of immobilization. The additional exposure of CFR treated animals to acute immobilization stress led to increased mRNA levels of TH by $380 \%(p<0.001$, Tukey test, Figure $2 \mathrm{a})$ and DBH by $150 \%(p<0.01$, Tukey test, Figure $2 \mathrm{~b}) 3 \mathrm{~h}$ after the cessation of acute immobilization. The additional exposure of chronically stressed animals to acute immobilization stress led to increased mRNA levels of TH by $280 \%(p<0.01$, Tukey test, Figure $2 a)$, DBH by $50 \%(p<0.05$, Tukey test, Figure $2 \mathrm{~b})$ and PNMT by $36 \%(p<0.05$, Tukey test, Figure $2 \mathrm{c}) 6 \mathrm{~h}$ after the cessation of immobilization.

Changes of TH, DBH and PNMT protein levels in the adrenal medulla

CFR treatment

CFR provoked the decreas protein levels of TH by $52 \%(p<0.01$, Tukey test, Figure $3 a)$ and of DBH by $20 \%(p<0.05$, Tukey test, Figure $3 b)$, compared with control animals. However, CFR induced the increase of PNMT protein level by $21 \%(p<0.05$, Tukey test, Figure 3c), compared with the controls.

\section{IMM and CFR+IMM treatment}

Exposure of the animals to acute immobilization stress, increased the protein level of TH by $10 \%(p<0.05$, Tukey test, Figure $3 a)$ and PNMT by $15 \%$ $(p<0.05$, Tukey test, Figure $3 c) 22 \mathrm{~h}$ after the cessation of immobilization. Additional exposure of CFR animals to acute immobilization stress led to increased protein levels of TH by $15 \%$ ( $p<0.05$, Tukey test, Figure $3 a)$, and PNMT 
by $30 \%(p<0.01$, Tukey test, Figure $3 c)$ 3h after the cessation of immobilization. In addition, exposure of CFR animals to acute immobilization stress led to increased protein level of $\mathrm{DBH}$ by $25 \%(\mathrm{p}<0.05$, Tukey test) $22 \mathrm{~h}$ after the cessation of immobilization (Figure 3b).

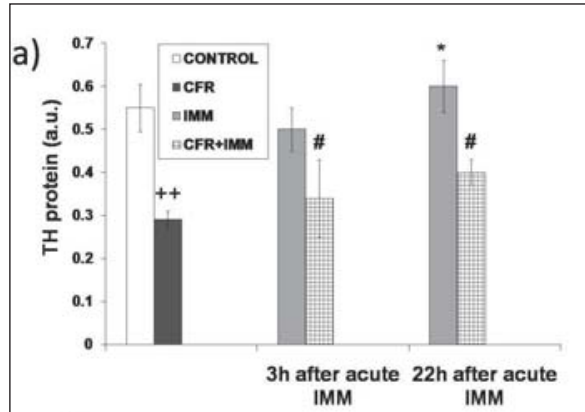

A)

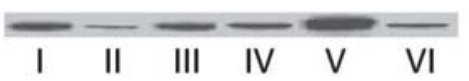

b)

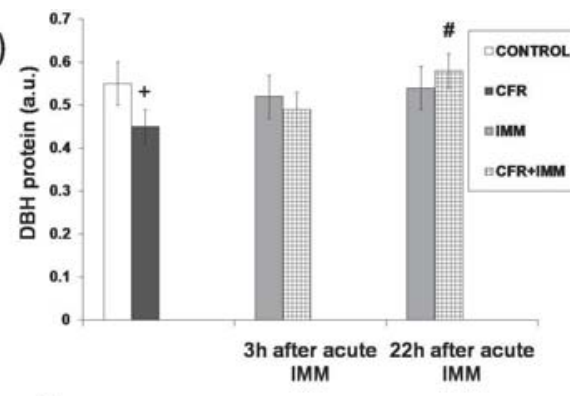

A)

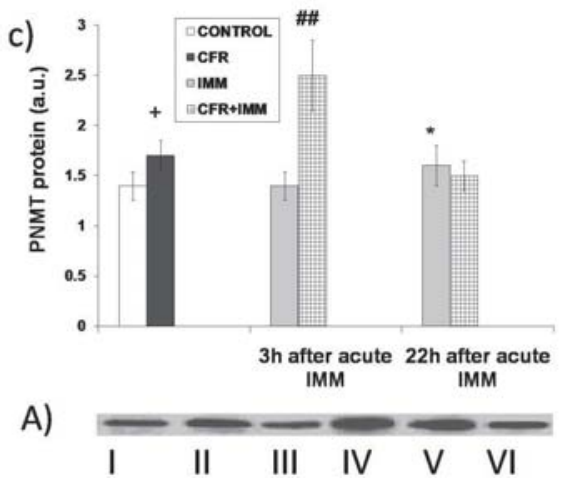

Figure 3. Figure 3. Effects of chronic forced running and additional acute immobilization stress on tyrosine hydroxylase $(\mathrm{TH})[\mathrm{a}]$, dopamine--3-hydroxylase $(\mathrm{DBH})[\mathrm{b}]$ and phenylethanolamine N-methyltransferase (PNMT) [c] protein levels in the adrenal medulla. The values are means \pm S.E.M. of 10 rats. Statistical significance: $+p<0.05$, $++p<0.01$ animals exposed to chronic forced running vs. control animals (Tukey test); ${ }^{*} \mathrm{p}<0.05$ animals exposed to acute $2 \mathrm{~h}$ immobilization vs. control animals (Tukey test); ${ }^{\#} p<0.05, \# \#<<0.01$ animals exposed to additional acute $2 \mathrm{~h}$ immobilization stress after chronic forced running vs. animals exposed to chronic forced running (Tukey test). The result was expressed in arbitrary units normalized in relation to $\beta$ actin.

(A) Distribution of TH, DBH and PNMT proteins in the adrenal medulla of control animals [I], animals exposed to CFR [II], animals exposed to IMM (3h after immobilization) [III], animals exposed to CFR+IMM (3h after immobilization) [IV], animals exposed to IMM (22h after immobilization) [V] and animals exposed to CFR+IMM (22h after immobilization) [VI]. 
Acta Veterinaria (Beograd), Vol. 62, No. 2-3, 151-169, 2012.

\section{DISCUSSION}

A number of diseases and pathological conditions are related to the longterm adaptive response to chronic stress. When the sympatho-adrenomedullary system is activated repeatedly over a long period of time the response is not only adaptive, but also maladaptive.

Changes in the plasma concentrations of CORT, NA, A and weight of adrenal gland

It is known that catecholamine hyperactivity and glucocorticoid disregulation are the biological consequences of chronic stress (Desaive and Ronson, 2008). The results of this study show that long-term treadmill running produced adaptive physiological changes which are indicative for chronic stress. The potentially negative physiological adaptations after CFR were recorded as increased in the concentration of catecholamine and decreased morning CORT concentrations in the plasma, as well as adrenal gland hypertrophy. Our results are consistent with previous reports. Pagliari and Peyrin (1995) observed that treadmill running stimulated concomitantly peripheral catecholamine secretion and central noradrenergic activity, i.e. NA turnover and release. Zouhal et al. (2008) found that physical training can increase the capacity of adrenaline secretion via an increase of the adrenal gland volume and adrenaline content.

Forced physical exercise, such as treadmill running, often produces negative physiological and psychopathological adaptations to stress responses accompanied by activation of corticotropin-releasing hormone $(\mathrm{CRH})$ neurons (Cullinan et al., 1995; Moraska et al., 2000; White-Welkley et al., 1996). However, the data regarding CORT concentration after exposing to chronic stress are conflicting (Cicchetti and Rogosch, 2001; Evans et al., 2001; Lupie et al., 2001; Yang et al., 2001). Previous findings of war-induced hypothalamic pituitaryadrenal (HPA) axis alterations showed both increased and unchanged cortisol concentrations (Roglic et al., 1993). Miachon et al. (1993) recorded that long-term stress induces a decreased CORT levels in blood. In this work we found that CFR decrease morning CORT in the plasma. Levels of CORT were measured in the morning because previous findings had shown that light is capable of eliciting a rapid CORT response in rats (Mohawk et al., 2007), humans (Leproult et al., 2001) and mice (Ishida et al., 2005). Žarković et al. (2003) found that chronic stress is associated with a transient suppression of the HPA axis, manifested by the lower morning CORT and the reduced adrenal CORT response to ACTH stimulation. The reduction of cortisol response is sufficient to cause a false diagnosis of HPA insufficiency. This HPA response pattern is manifested by decreased morning plasma or urinary cortisol, especially in the subjects with post-traumatic stress disorder (PTSD) (Yehuda et al., 1995, 2002; Goenjian et al., 1996; Heim et al., 2001; King et al., 2001). It is interesting to note that reduced concentrations of CORT in the plasma were recorded in depressed conditions (Malkesman et al., 2006).

Adrenal hypertrophy found in our experiments may be interpreted as a consequence of chronic stress conditions. Westenbroek et al. (2003) consider 
that the weight of the adrenal gland may be a reliable criterion of the experienced chronic stress and may serve as the evidence of depressive conditions. Hypertrophy of the adrenal glands has also been found in depressed patients (Nemeroff et al., 1992; Rubin et al., 1996), indicating that adrenal size provides a good measure of the stress perception over periods of time.

Response to acute IMM stress is characterized by the activation of the sympatho-adrenomedullary system and the HPA axis. This is manifested as a short-term increase in NA, A and cortisol concentrations (Chatterton et al., 1997; Dugue et al., 2001; Gerra et al., 2001; Habib et al., 2001). In this work, we recorded that chronically stressed rats (CFR) exposed to novel, additional, acute stress have significantly increased concentrations of catecholamines and CORT in the plasma. Kvetnansky et al. (2009) recorded that the exaggerated levels of both plasma NA and $A$ in rats exposed to chronic stress might be a consequence of the readiness of such animals to respond to altered quality or quantity of an additional stressor. Our results show that the heterotypic novel stressor (IMM) triggers an exaggerated elevation in plasma catecholamines in animals previously exposed to CFR, even $22 \mathrm{~h}$ after exposure. It is the readiness of the organism prolongly exposed to homotypic stressors to respond to a heterotypic stressor by an exaggerated activation of catecholamines that it is considered to be an important adaptive phenomenon of the sympatho-adrenomedullary system in rats (Kvetnansky et al., 2009). Our results together with the above mentioned data show that the CFR induce adaptations that are indicative for chronic stress.

Changes of the TH, DBH and PNMT gene expression in the adrenal medulla

Most significant observation in this work is that CFR stress induces changes on different levels of gene expression of cateholamine biosynthetic enzymes in the adrenal medulla. We found that CFR induces the decreases TH and DBH mRNA and protein levels in the adrenal medulla. Our results are consistent with the results of Lelkes et al. (1994), who found a reduction of TH gene expression in the adrenal medulla of rats exposed to the direct impact of microgravity (up to $10^{-6} \mathrm{~g}$ ) in a space shuttle. Tümer et al. (1992) observed that exercise reduced levels of TH mRNA in the adrenal medulla. Considering the changes at the molecular level, it is important to note that gene expression in stress response depends on the duration and type of stress, as well as on the cell type. For these reasons, we analyzed the transcription factors involved in the down regulation of $\mathrm{TH}$ and $\mathrm{DBH}$ gene expression. In the adrenal medulla, the DNA-binding activities of activating protein-1 (AP-1) and CREB play a major role in regulating the expression of TH and DBH genes during forced exercise (Erdös et al., 2007). Transcription factor CREB may be important in establishing the stress-induced patterns of gene expression. It is interesting to note that Rosenberg et al. (2003) observed the reduction of CREB protein expression in the majority of adrenocortical tumors. Peri et al. (2001) observed that changes in cAMP signaling may be associated with malignities of the adrenal cortex. Our results demonstrate that the reduced level of CREB mRNA coincides with the reduced TH and DBH mRNA levels. Many authors have confirmed that chronic stress is associated with the reduction of phospho-CREB expression (McEwen 2003; Nestler et al., 2002; 
Trentani et al., 2002; Kuipers et al., 2003, 2006). Trentani et al. (2002) showed that in male rats chronically exposed to a mild electrostimulation, phospho-CREB expression was reduced, especally in the subcortical and cortical region. Wang et al. (2006) observed that chronic stress significantly reduces the expression of cAMP dependent kinase A (PKA) and phospho-CREB in the hippocampus of rats. However, in stressed rats treated with fluoxetine, the expression of phosphoCREB was significantly increased, which indicates that chronic stress can affect the PKA and phospho-CREB expression, and that the antidepressant is an antagonist.

Decreased TH and DBH gene expression may be the consequence of a decreased activity of the sympathetic nervous system and the reduced amount of acetylcholine (AchE) released from the preganglionic sympathetic nerve endings which innervates chromaffin cells in the adrenal medulla. In addition, the changes that occur on the molecular level may be the result of the action of micro-RNA (miRNA). It is known that micro-RNA is a small non-coding RNA that has the crucial role in the post-transciptional gene regulation. It joins to the complementary site on mRNA and then leads to the splitting and degradation of mRNA. Many mRNAs coding the transcription factors that regulate the expression of many downstream genes are the targets for numerous miRNAs.

Glucocorticoids are involved in the regulation of $\mathrm{TH}$ and $\mathrm{DBH}$ gene expression (Tank et al., 1986; Hwang and Joh, 1993). We found that CFR induces the decrease of TH and DBH mRNA level in the adrenal medulla which coincides with the decrease of CORT concentration in the plasma.

However, a significant result in this work is that CFR does not affect de novo synthesis of TH enzyme, but increases the concentration of NA in plasma. Many factors can affect the activity of TH enzyme, without changing its expression. One answer may be in the intracellular level of tetrahydrobiopterin which can be altered by stress and sympathetic nervous activity and thus may affect the activity of $\mathrm{TH}$, without changing the level of the enzyme (Baruchin et al., 1990). Many studies have shown that noncholinergic neurotransmitters affect the biosynthesis of catecholamines. Bobrovskaya et al. (2007) found that the amount of $\mathrm{TH}$ enzyme is regulated by pituitary adenylate cyclase-activating peptide (PACAP). Specifically, prolonged activation of TH enzyme resulting from phosphorylation of $\mathrm{TH}$ at Ser 40, can maintain the synthesis of catecholamine without synthesis of $\mathrm{TH}$ enzyme. Although expression of $\mathrm{TH}$ and $\mathrm{DBH}$ gene is decreased after CFR treatment regimes, this treatment may lead to continuous increased biosynthesis of NA, as well as increased release of NA in plasma, which might represent an adaptation on the applied stress regime. Also, it is important that the sympathetic nervous system (stellate ganglia) may be a source of NA in the circulation after chronic stress. In our previous work (Gavrilovic et al. 2009), we found that chronic stress causes the increase of $\mathrm{TH}$ and $\mathrm{DBH}$ gene expressions in stellate ganglia. Increased synthesis of $\mathrm{TH}$ and $\mathrm{DBH}$ enzymes in stellate ganglia causes the increase in NA plasma levels, which is in accordance with the reports of Sabban et al. (2004).

Glucocorticoids are important regulators of PNMT gene expression. In this work, we observed that CFR induce the decrease of PNMT mRNA level in the 
adrenal medulla which coincides with the decrease of CORT concentration in the plasma. Studies on the hypophysectomised rats have shown that reduced amounts of corticosteroids cause the reduction of PNMT mRNA level (Evinger et al., 1992; Wong et al., 1992; 1995; Krizanova et al., 2001). It is possible that suppressed splanhic inervation of the chromaffin cells in the adrenal medulla due to chronic stress, also affects PNMT mRNA level. A significant result in this study is that CFR induce the increase of PNMT protein level in the adrenal medulla, with the consequent increase of $A$ level in the plasma. It is interesting to note that although PNMT mRNA is decreased after CFR treatment regimes, this treatment may lead to continuous accumulation of its proteins as an adaptation on applied stress regime.

Acute stress immobilization induces increased expression of all examined genes in the adrenal medulla. This shows that the increased level of cateholamines in the plasma after acute immobilization originates from the adrenal medulla. Acute immobilization only does not change the expression of the DBH gene. Nankova et al. (1999) found that DBH gene expression changes are caused by prolonged or repeated stress. Chronically stressed animals have statistically more significant expression of $\mathrm{TH}, \mathrm{DBH}$ and PNMT genes after additional acute immobilization stress compared with animals exposed to acute stress immobilization only. This means that the adrenal medulla in animals exposed to chronic stress, is more sensitive to additional acute stress, compared to the animals exposed to acute immobilization. Our results confirm that the CFR shows adaptations that are indicative for chronic stress.

\section{CONCLUSION}

The increased synthesis of PNMT enzyme in the adrenal medulla may result in an increased biosynthesis of $A$ under the chronic stress conditions. Additionally, increased level of catecholamines in the plasma after chronic intensive physical stress is the allostatic load that may induce numerous diseases and pathological conditions.

ACKNOWLEDGMENTS:

This work was supported by the Ministry of Education and Science of the Republic of Serbia, Contract No. III 41027 III 41022 and OI 173044.

Address for correspondence:

Ljubica Gavrilović, Ph.D.

Institute of Nuclear Sciences „Vinča”

Laboratory of Molecular Biology and Endocrinology

P.O.B. $522-090$

11000 Belgrade, Serbia

E-mail: gljubica@vinca.rs 


\section{REFERENCES}

1. Baruchin A, Weisberg EP, Miner LL, Ennis D, Nisenbaum LK, Naylor E et al., 1990, Effects of cold exposure on rat adrenal tyrosine hydroxylase: an analysis of RNA, protein, enzyme activity, and cofactor levels, J Neurochem, 54, 1769-75.

2. Bobrovskaya L, Gelain DP, Gilligan C, Dickson PW, Dunkley PR, 2007, PACAP stimulates the sustained phosphorylation of tyrosine hydroxylase at serine 40, Cell Signal, 19, 6, 1141-9.

3. Chatterton RT Jr, Vogelsong KM, Lu YC, Hudgens GA, 1997, Hormonal responses to psychological stress in men preparing for skydiving, J Clin Endocrinol Metabol, 82, 2503-9.

4. Cicchetti $D$, Rogosch FA, 2001, Diverse patterns of neuroendocrine activity in maltreated children, Develop Psychopathol, 13, 677-93.

5. Cullinan W, Herman J, Battaglia D, Akil H, Watson S, 1995, Pattern and time course of immediate early gene expression in rat brain following acute stress, Neuroscience, 64, 2, 477-505.

6. Desaive $P$, Ronson A, 2008, Stress spectrum disorders in oncology, Curr Opin Oncol, 20, 4, 378-85.

7. Dugue B, Leppanen E, Grasbeck R, Benoit D, Esa L, Ralph G, 2001, The driving license examination as a stress model: effects on blood picture, serum cortisol and the production of interleukins in man, Life Scences 68, 1641-7.

8. Erdös B, Broxson CS, Landa T, Scarpace PJ, Leeuwenburgh C, Zhang Y et al., 2007, Effects of lifelong caloric restriction and voluntary exercise on age-related changes in levels of catecholamine biosynthetic enzymes and angiotensin II receptors in the rat adrenal medulla and hypothalamus, Exp Gerontol, 42, 8, 745-52.

9. Evans GW, Lercher P, Meis M, Ising H, Kofler WW, 2001, Community noise exposure and stress in children, J Acoust Soc Am, 109, 1023-7.

10. Evinger MJ, Towle AC, Park DH, Lee P, Joh TH, 1992, Glucocorticoids stimulate transcription of the rat phenylethanolamine $\mathrm{N}$-methyltransferase (PNMT) gene in vivo and in vitro, Cell $\mathrm{Mol}$ Neurobiol, 12, 3, 193-215.

11. Gavrilovic L, Spasojevic N, Dronjak S, 2009, Psychosocial stress-related changes in gene expression of norepinephrine biosynthetic enzymes in stellate ganglia of adult rats, Auton Neurosci Oct, 5, 150, 1-2, 144-6.

12. Gerra G, Zaimovic A, Mascetti GG, Gardini S, Zambelli U, Timpano M et al., 2001, Neuroendocrine responses to experimentally-induced psychological stress in healthy humans, Psychoneuroendocrinology, 26, 91-107.

13. Goenjian AK, Yehuda R, Pynoos RS, Steinberg AM, Tashjian M, Yang RK et al., 1996, Basal cortisol, dexamethasone suppression of cortisol, and MHPG in adolescents after the 1988 earthquake in Armenia, Am J Psychiatry, 153, 929-34.

14. Habib KE, Gold PW, Chrousos GP, 2001, Neuroendocrinology of stress, Endocrinol Metabol Clin North Am, 30, 695-728.

15. Heim C, Newport DJ, Bonsall R, Miller AH, Nemeroff CB, 2001, Altered pituitary-adrenal axis responses to provocative challenge tests in adult survivors of childhood abuse, Am $J$ Psychiatry, 158, 575-81.

16. Hwang O, Joh TH, 1993, Effects of cAMP, glucocorticoids, and calcium on dopamine betahydroxylase gene expression in bovine chromaf-fin cells, J Mol Neurosci, 4, 173-83.

17. Ishida A, Mutoh T, Ueyama T, Bando H, Masubuchi S, Nakahara D et al., 2005, Light activates the adrenal gland: timing of gene expression and glucocorticoid release, Cell Metab, 2, 297-307.

18. King JA, Mandansky D, King S, Fletcher KE, Brewer J, 2001, Early sexual abuse and low cortisol, Psychiatry Clin Neurosci, 55, 71-4.

19. Krizanova O, Micutkova L, Jelokova J, Filipenko M, Sabban E, Kvetnansky R et. al., 2001, Existence of cardiac PNMT mRNA in adult rats: elevation by stress in a glucocorticoid-dependent manner, Am J Physiol Heart Circ Physiol, 281, H1372-9.

20. Kumer SC, Vrana KE, 1996, Intricate regulation of tyrosine hydroxylase activity and gene expression, J Neurochem, 67, 2, 443-62.

21. Kuipers SD, Trentani A, Den Boer JA, Ter Horst GJ, 2003, Molecular correlates of impaired prefrontal plasticity in response to chronic stress, J Neurochem, 85, 5, 1312-23. 
22. Kuipers SD, Trentani A, Westenbroek C, Bramham CR, Korf J, Kema IP et al., 2006, Unique patterns of FOS, phospho-CREB and BrdU immunoreactivity in the female rat brain following chronic stress and citalopram treatment, Neuropharmacology, 50, 4, 428-40.

23. Kvetnansky R, Micutkova L, Kubovcakova L, Sabban EL, Palkovits M, Krizanova O, 2004, Localization and regulation of phenylethanolamine $\mathrm{N}$-methyltransferase gene expression in the heart of rats and mice during stress, Ann NY Acad Sci, 1018, 405-17.

24. Kvetnansky R, Micutkova L, Rychkova N, Kubovcakova L, Mravec B, Filipenko $M$ et al., 2004, Quantitative evaluation of catecholamine enzymes gene expression in adrenal medulla and sympathetic ganglia of stressed rats, Ann NY Acad Sci, 1018, 356-69.

25. Kvetnansky R, Mikulaj L, 1970, Adrenal and urinary catecholamines in rats during adaptation to repeated immobilization stress, Endocrinology, 87, 738-43.

26. Kvetnansky R, Sabban EL, Palkovits M, 2009, Catecholaminergic Systems in Stress: Structural and Molecular Genetic Approaches, Physiol Rev, 89, 535-606

27. Laemmli UK, 1970, Cleavage of structural proteins during the assembly of the head of bacteriophage T4, Nature, 227, 680-5.

28. Lelkes PI, Ramos EM, Chick DM, Liu J, 1994, Unsworth BR. Microgravity decreases tyrosine hydroxylase expression in rat adrenals, FASEB J, 8, 14, 1177-82.

29. Leproult R, Colecchia EF, L'Hermite-Baleriaux M, Van Cauter E, 2001, Transition from dim to bright light in the morning induces an immediate elevation of cortisol levels, J Clin Endocrinol Metab, 86, 151-7.

30. Lewis EJ, Harrington CA, Chikaraishi DM, 1987, Transcriptional regulation of the tyrosine hydroxylase gene by glucocorticoid and cyclic AMP, Proc Natl Acad Sci USA, 84, 11, 3550-4.

31. Livak KJ, Schmittgen TD, 2001, Analysis of relative gene expression data using real-time quantitative PCR and the 2 (-Delta Delta C(T)) Method, Methods, 25, 402-8.

32. Lupie SJ, King S, Meaney MJ, McEwen BS, 2001, Can poverty get under your skin? Basal cortisol levels and cognitive function in children from low and high socioeconomic status, Dev Psychopathol, 13, 653-76.

33. Malkesman O, Maayan R, Weizman A, Weller A, 2006, Aggressive behavior and HPA axis hormones after social isolation in adult rats of two different genetic animal models for depression, Behav Brain Res, 175, 408-14.

34. McEwen BS, 2003, Mood disorders and allostatic load, Biol Psychiatry, 1, 54, 3, 200-7.

35. McMahon A, Sabban EL, 1992, Regulation of expression of dopamine beta-hydroxylase in PC12 cells by glucocorticoids and cyclic AMP analogues, $J$ Neurochem, 59, 2040-7.

36. Miachon S, Rochet T, Mathian B, Barbagli B, Claustrat B, 1993, Long-term isolation of Wistar rats alters brain monoamine turnover, blood corticosterone and ACTH, Brain Res Bull, 32, 611-4.

37. Mohawk JA, Pargament JM, Lee TM, 2007, Circadian dependence of corticosterone release to light exposure in the rat, Physiol Behav, 5, 92, 5, 800-6.

38. Moraska A, Deak T, Spencer RL, Roth D, Fleshner M, 2000, Treadmill running produces both positive and negative physiological adaptations in Sprague-Dawley rats, Am J Physiol Regul Integr Comp Physiol, 279, 1321-9.

39. Nagatsu T, Levitt M, Uddenfriend S, 1964, Tyrosine hydroxylase. The initial step in norepinephrine biosynthesis, J Biol Chem, 239, 2910-7.

40. Nankova BB, Tank AW, Sabban EL, 1999, Transient or sustained transcriptional activation of the genes encoding rat adrenomedullary catecholamine biosynthetic enzymes by different durations of immobilization stress, Neuroscience, 94, 803-8.

41. Nemeroff CB, Krishnan KRR, Reed D, Leder R, Beam C, Dunnick NR, 1992, Adrenal gland enlargement in major depression: a computed tomography study, Arch Gen Psychiatry, 49, 384-7.

42. Nestler EJ, Barrot M, DiLeone RJ, Eisch AJ, Gold SJ, Monteggia LM, 2002, Neurobiology of depression, Neuron, 28, 34, 1, 13-25.

43. Núñez C, Földes A, Pérez-Flores D, García-Borrón JC, Laorden ML, Kovács KJ et al., 2009, Elevated glucocorticoid levels are responsible for induction of tyrosine hydroxylase mRNA expression, 
phosphorylation, and enzyme activity in the nucleus of the solitary tract during morphine withdrawal, Endocrinology, 150, 7, 3118-27.

44. Pagliari R, Peyrin L, 1995, Physical conditioning in rats influences the central and peripheral catecholamine responses to sustained exercise, Eur J Appl Physiol Occup Physiol, 71, 1, 41-52.

45. Peri A, Luciani P, Conforti B, Baglioni-Peri S, Cioppi F, Crescioli C et al., 2001, Variable expression of the transcription factors cAMP response element-binding protein and inducible cAMP early repressor in the normal adrenal cortex and in adrenocortical adenomas and carcinomas, $J$ Clin Endocrinol Metab, 86, 11, 5443-9.

46. Peuler JD, Johnson GA, 1977, Simultaneous single isotope radioenzymatic assay of plasma norepinephrine, epinephrine and dopamine, Life Sci, 21, 625-36.

47. Roglic G, Pibernik-Okanovic M, Prasek M, Metelko Z, 1993, Effect of war-induced prolonged stress on cortisol of persons with type II diabetes mellitus, Behav Med, 19, 53-9.

48. Rosenberg D, Groussin L, Jullian E, Perlemoine K, Medjane S, Louvel A et al., 2003, Transcription factor $3^{\prime}, 5^{\prime}$-cyclic adenosine $5^{\prime}$-monophosphate-responsive element-binding protein (CREB) is decreased during human adrenal cortex tumorigenesis and fetal development. $J$ Clin Endocrinol Metab, 88, 8, 3958-6.

49. Ross ME, Evinger MJ, Hyman SE, Carroll JM, Mucke L, Comb M et al., 1990, Identification of a functional glucocorticoid response element in the phenylethanolamine Nmethyltransferase promoter using fusion genes introduced into chromaffin cells in primary culture, J Neurosci, 10, 520-30.

50. Rubin RT, Phillips JJ, McCracken JT, Sadow TF, 1996, Adrenal gland volume in major depression: relationship to basal and stimulated pituitary-adrenal cortical axis function, Biol Psychiatry, 40, 89-97.

51. Sabban EL, Nankova BB, Serova LI, Kvetnansky R, Liu X, 2004, Molecular regulation of gene expression of catecholamine biosynthetic enzymes by stress: sympathetic ganglia versus adrenal medulla, Ann NY Acad Sci, 1018, 370-7.

52. Stich TM, 1990, Determination of protein covalently bound to agarose supports using bicinchoninic acid, Ann Biochem, 191, 343-6.

53. Swanson DJ, Adachi M, Lewis EJ, 2000, The homeodomain protein Arix promotes protein kinase A-dependent activation of the dopamine beta-hydroxylase promoter through multiple elements and interaction with the coactivator cAMP-response element-binding protein-binding protein, $J$ Biol Chem, 275, 2911-23.

54. Tai TC, Claycomb R, Her S, Bloom AK, Wong DL, 2002, Glucocorticoid responsiveness of the rat phenylethanolamine N-methyltransferase gene, Mol Pharmacol, 61, 1385-92.

55. Tank AW, Ham L, Curella $P, 1986$, Induction of tyrosine hydroxylase by cyclic AMP and glucocorticoids in a rat pheochromocytoma cell line: effect of the inducing agents alone or in combination on the enzyme levels and rate of synthesis of tyrosine hydroxylase, $\mathrm{Mol}$ Pharmacol, 30, 5, 486-96.

56. Trentani A, Kuipers SD, Ter Horst GJ, Den Boer JA, 2002, Selective chronic stress-induced in vivo ERK1/2 hyperphosphorylation in medial prefrontocortical dendrites: implications for stressrelated cortical pathology? Eur J Neurosci, 15, 10, 1681-91.

57. Tümer N, Hale C, Lawler J, Strong R, 1992, Modulation of tyrosine hydroxylase gene Expression in the rat adrenal gland by exercise: effects of age, Mol Brain Res, 14, 51-6.

58. Wang Z, Hu SY, Lei DL, Song WX, 2006, Effect of chronic stress on PKA and P-CREB expression in hippocampus of rats and the antagonism of antidepressors Zhong Nan Da Xue Xue Bao Yi Xue Ban, 31, 5, 767-71.

59. Westenbroek C, Ter Horst GJ, Roos MH, Kuipers SD, Trentani A, den Boer JA, 2003, Genderspecific effects of social housing in rats after chronic mild stress exposure, Prog Neuropsychopharmacol Biol Psychiatry, 27, 1, 21-30.

60. White-Welkley J, Warren G, Bunnell B, Mougey E, Meyerhoff J, Dishman R, 1996, Treadmill exercise training and estradiol increase plasma ACTH and prolactin after novel footshock, $J$ Applied Physiol, 80, 3, 931-9. 
61. Wong $D L$, Lesage A, White $S$, Siddall B, 1992, Adrenergic expression in the rat adrenal gland: multiple developmental regulatory mechanisms, Brain Res Dev Brain Res, 19, 67, 2, 229-36.

62. Wong DL, Siddall B, Wang W, 1995, Hormonal control of rat adrenal phenylethanolamine Nmethyltransferase. Enzyme activity, the final critical pathway, Neuropsychopharmacology, 13, 3, 223-34

63. Yang Y, Koh D, Ng V, Lee FC, Chan G, Dong F et al., 2001, Salivary cortisol levels and work-related stress among emergency department nurses, J Occup Environ Med, 43, 1011-8.

64. Yehuda R, Halligan SL, Bierer LM, 2002, Cortisol levels in adult offspring of Holocaust survivors: relation to PTSD symptom severity in the parent and child, Psychoneuroendocrinology, 27, 171-80.

65. Yehuda R, Kahana B, Binder-Brynes K, Southwick SM, Mason JW, Giller EL, 1995, Low urinary cortisol excretion in Holocaust survivors with posttraumatic stress disorder, Am J Psychiatry, $152,982-6$.

66. Zouhal H, Jacob C, Delamarche P, Gratas-Delamarche A, 2008, Catecholamines and the effects of exercise, training and gender, Sports Med, 38, 5, 401-23. Review.

67. Žarković M, Stefanova E, Cirić J, Penezić Z, Kostić V, Sumarac-Dumanović M et al., 2003, Prolonged psychological stress suppresses cortisol secretion, Clin Endocrinol (Oxf), 59, 6, 811-6.

\title{
HRONIČNI FIZIČKI STRES MENJA EKSPRESIJU GENA ZA BIOSINTEZU KATEHOLAMINA U SRŽI NADBUBREŽNE ŽLEZDE KOD ODRASLIH PACOVA
}

\author{
GAVRILOVIĆ LJUBICA, STOJILJKOVIĆ VESNA, KASAPOVIĆ JELENA, PEJIĆ SNEŽANA, \\ TODOROVIĆ ANA, PAJOVIĆ B SNEŽANA i DRONJAK SLADJANA
}

\section{SADRŽAJ}

U ovom radu je proučavan uticaj hroničnog prisilnog trčanja (CFR) na ekspresiju gena za enzime koji učestvuju u biosintezi kateholamina, na ekspresiju transkripcionog faktora CREB u srži nadbubrežnih žlezda i na težinu nadbubrežnih žlezda pacova. Takođe je ispitano i kako CFR i dodatni akutni stres imobilizacijom utiču na ekspresiju gena za enzime koji učestvuju u biosintezi kateholamina u srži nadbubrežnih žlezda i kako pomenuti stresori utiču na koncentracije kateholamina i kortikosterona (CORT) u plazmi.

U eksperimentu je korišćen model prisilnog vežbanja kod pacova (trčanje po pokretnoj traci). Za određivanje nivoa ekspresije gena korišćena je najsavremenija metoda, real-time PCR sa TakMan probama, kao i Western blot (ECL) analiza.

Utvrđeno je da CFR smanjuje nivoe iRNK i proteina za tirozin hidroksilazu (TH) i dopamin beta hidroksilazu (DBH) u srži nadbubrežnih žlezda. Smanjeni nivoi iRNK za TH i DBH podudaraju se sa smanjenim nivoom iRNK za CREB u srži nadbubrežnih žlezda kao i sa smanjenim nivoom CORT u plazmi. Pored toga, CFR smanjuje nivo iRNK za feniletanolamin N-metiltransferazu (PNMT), ali podiže nivo PNMT proteina u srži nadbubrežnih žlezda i povećava koncentraciju adrenalina (A) u plazmi. Smanjen nivo iRNK za PNMT u srži nadbubrežnih žlezda podudara se sa smanjenim nivoom CORT u plazmi. Dodatni akutni stres imobilizacije 
Acta Veterinaria (Beograd), Vol. 62, No. 2-3, 151-169, 2012.

Gavrilović Ljubica et al.: Chronic physical stress changes gene expression

of catecholamine biosynthetic enzymes in the adrenal medulla of adult rats

povećava ekspresiju gena za enzime koji učestvuju u biosintezi kateholamina u srži nadbubrežnih žlezda, kao i koncentraciju kateholamina i CORT u plazmi.

Povećana sinteza PNMT enzima u srži nadbubrežnih žlezda može dovesti do povećane biosinteze A u uslovima hroničnog stresa. Pored toga, povećan nivo kateholamina u plazmi, posle hroničnog fizičkog stresa, predstavlja alostatičko opterećenje koje može dovesti do brojnih oboljenja i patoloških stanja. 